\title{
SERUM FLUORESCENT ANTIBODY AND IMMUNOGLOBULIN ESTIMATIONS IN CANDIDOSIS
}

\author{
T. LEHNER \\ Department of Oral Medicine and Pathology, Guy's Hospital, London
}

FROM the results of the titration of 244 sera (including 76 from cases of candidosis) in an indirect fluorescent antibody test against films of Candida albicans, Lehner $(1965,1966$ a) concluded that a titre greater than 16 was evidence of candidosis. Titres in controls were 8 or less, and those in candida carriers up to 16. These findings were confirmed by Esterly (1968) in a series of 207 sera. Both these investigations used whole anti-human-globulin conjugates so that the immunoglobulin class of candida antibodies has not been determined. However, in a preliminary study Esterly used monospecific conjugates and found IgG and IgA type of candida antibodies.

The immunoglobulin class of candida antibodies is of interest, in view of the frequent involvement of mucous membranes and its possible association with IgA type of antibodies. Controls and patients with different varieties of candidosis might also show a specific pattern of immunoglobulin class of candida antibodies. The serum fluorescent antibody titre was therefore determined in 65 subjects, by the use of specific IgG, IgA and IgM conjugates, and the results for controls were compared with those for patients with four varieties of candidosis. A number of selected sera were fractionated by DEAE cellulose chromatography, in order to assess the immunoglobulin class of candida antibodies, and the specificity of the conjugates. The concentration of serum IgG, IgA and IgM was also estimated and then compared between the controls and patients with candidosis, and with the candida antibody titres of the corresponding immunoglobulin class.

\section{MATERIALS AND METHODS}

Subjects. Venous blood was taken from 65 subjects; the serum was allowed to separate and was then stored at $-20^{\circ} \mathrm{C}$. There were 28 controls, a group that included persons without oral disease, or patients with recurrent aphthous ulceration or leukoplakia. The 37 patients with candidosis were divided into four groups (table I), according to the classification described previously (Lehner, 1963, 1966b). Five of the 12 patients with chronic hyperplastic candidosis had the endocrine candidosis syndrome, or chronic localised mucocutaneous candidosis, and four of the eight patients with chronic atrophic candidosis had Sjøgren's syndrome.

Candida albicans antigen. The organism was grown on Sabouraud's agar from a patient with chronic hyperplastic candidosis. It formed chlamydospores and germ tubes, and was maintained by subculture on Sabouraud's agar. A suspension of candida was prepared by harvesting the organisms, washing them twice with saline and then resuspending them in 0.4 per cent. formaldehyde in saline to a density of approximately $70 \times 10^{6}$ yeast cells

Received 2 Oct. 1969; accepted 16 Jan. 1970.

J. MED. MICROBIOL.-VOL. 3 (1970)

475 
per $\mathrm{ml}$. The smears were prepared by placing a loopful of the antigen suspension on a slide and heating it over a flame.

Fluorescent antibody test. The indirect technique was used with serial dilutions of serum, as described previously (Lehner, 1966a). Anti-human-IgG conjugated with fluorescein isothiocyanate (FITC) was supplied by courtesy of the Medical Research Council, Blood Group Reference Laboratory. Anti-human-IgA-, IgM-, and "triple" FITC conjugate (containing antiserum to the three human immunoglobulins) were obtained from Baxter Laboratories Ltd. The specificity of these was established by immuno-electrophoresis (Scheidegger, 1955), by blocking each conjugate with the corresponding unconjugated antiserum and by using the three chromatographic fractions with each of the three immunoglobulin conjugates. Light-chain cross-reactivity in the IgG and IgM conjugates was not revealed by testing these with parotid saliva containing only $\operatorname{IgA}$ antibodies. The FITC: protein ratio of each conjugate was determined spectrophotometrically by the ratio of absorption at $492 \mathrm{~nm}$ and $280 \mathrm{~nm}$; these were 0.91 for IgG, 0.89 for IgA and 0.99 for IgM. Each test series included a negative control with saline, and a known positive serum.

$D E A E$ cellulose chromatography was performed on five selected sera; a pooled serum from four patients with oral candidosis, another serum from a patient with oral candidosis, and three control sera. The method was that of Levy and Sober (1960) as described previously (Lehner, 1969), and the fractions were examined by immuno-electrophoresis.

Immunoglobulin estimation. Serum IgG, IgA and IgM were estimated by the immunochemical method described by Mancini, Carbonara and Hereman (1963). The reagents were supplied by Baxter Laboratories Ltd, and the tests for specificity of the antisera were performed by immuno-electrophoresis and immunodiffusion (Lehner, 1969).

\section{RESULTS}

\section{Fluorescent antibodies}

The criterion of a positive reaction was the complete bright-green fluorescent ring around candida cells; the reactions produced by the three immunoglobulin classes of candida antibodies were indistinguishable. The titre of the IgG and IgA class of all but one serum from control subjects did not exceed 16 and that of IgM 8 (table I). IgG and IgA antibody titres greater than 16 , and IgM titres over eight were therefore adopted to indicate present or past infection with candida. A raised titre was shown by patients with candidosis in 29 out of 37 ( 78 per cent.) cases in the IgG class $(\mathrm{P}<0.01)$, 11 out of 37 (30 per cent.) in $\operatorname{IgA}(\mathrm{P}<0.01)$ and 19 out of 37 (51 per cent.) in IgM type of antibody $(\mathrm{P}<0.001)$. The highest titre recorded was 2048 with $\operatorname{IgG}, 256$ with $\operatorname{IgA}$ and 128 with IgM.

Some differences were revealed in the type of antibody response between the four groups of candidosis (table II); most of them yielded a raised IgG titre, but $\operatorname{IgA}$ and $\operatorname{IgM}$ class of antibodies were found predominantly in acute pseudomembranous and chronic atrophic candidosis. Sera from acute atrophic candidosis gave the lowest antibody titres. The " triple " antiserum conjugate to $\operatorname{IgG}, \operatorname{IgA}$ and $\operatorname{IgM}$ yielded comparable antibody levels to those of the $\operatorname{IgG}$ but not to the other two conjugates (not shown). The titres with the "triple" conjugate were not higher than any of those resulting from the use of the monospecific conjugates.

Candida antibodies were found in the three serum fractions separated by DEAE cellulose chromatography (figure; table III). The results suggest that the monospecific conjugates react with their own immunoglobulin class; 


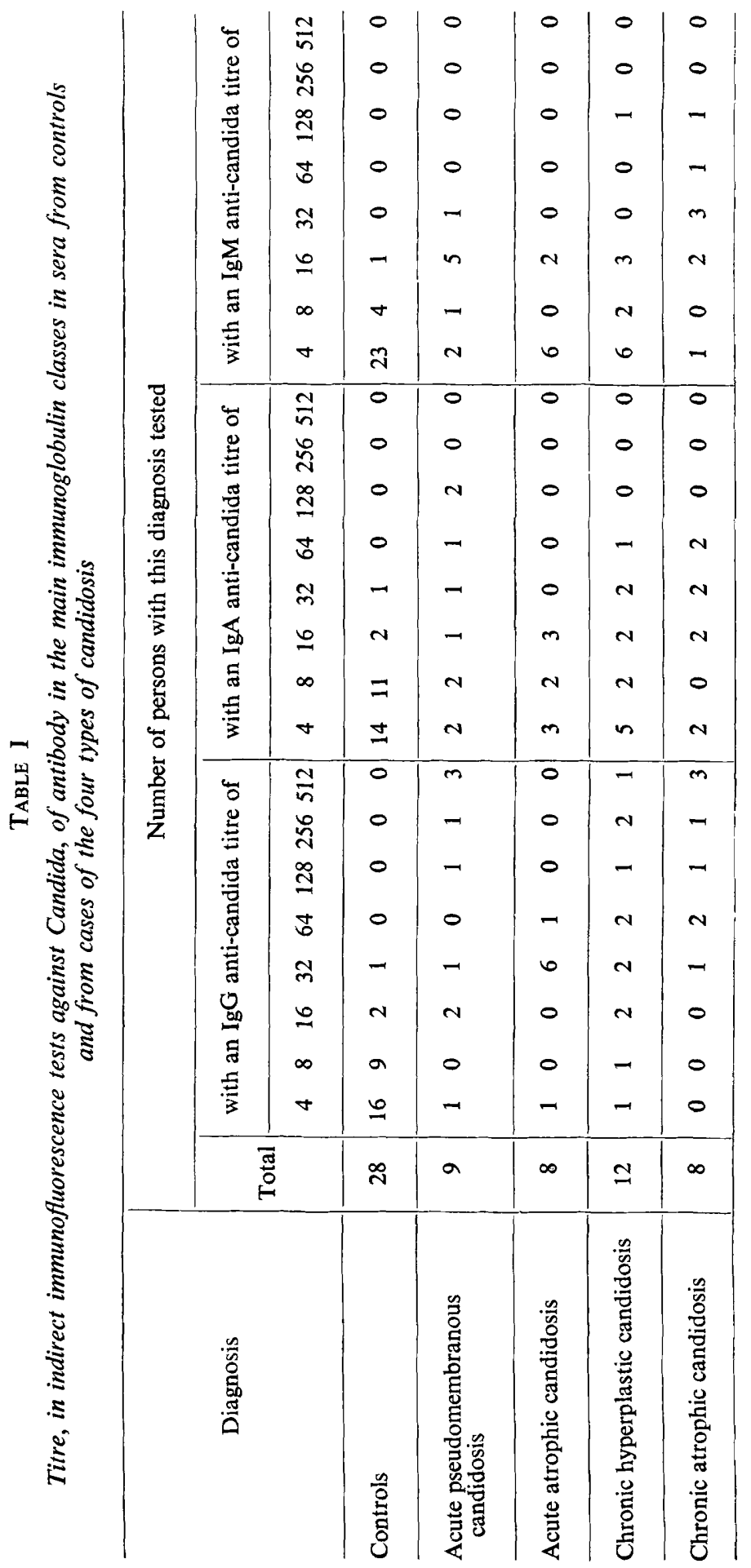


the low titre of heterospecific antibodies in fraction II and III with IgG and IgA conjugates, respectively (pooled serum; table III), and in fraction I

TABLE II

The immunoglobulin class of fluorescent antibodies to Candida albicans in patients with candidosis and in controls

\begin{tabular}{lr|c|c|l|l}
\hline \multirow{2}{*}{ Diagnosis } & \multirow{2}{*}{$\begin{array}{c}\text { Number of } \\
\text { subjects }\end{array}$} & \multicolumn{2}{|c}{$\begin{array}{c}\text { Number (and per cent.) of } \\
\text { subjects with antibody titre in }\end{array}$} \\
\cline { 5 - 7 } & & & IgG $>16$ & IgA $>16$ & IgM $>8$ \\
\hline Controls . & $\cdot$ & 28 & $1(4)$ & $1(4)$ & $1(4)$ \\
Acute pseudomembranous candidosis . & 9 & $6(66)$ & $4(44)$ & $6(66)$ \\
Acute atrophic candidosis . & $\cdot$ & 8 & $7(88)$ & 0 & $2(25)$ \\
Chronic hyperplastic candidosis . & $\cdot$ & 12 & $8(66)$ & $3(25)$ & $4(33)$ \\
Chronic atrophic candidosis & $\cdot$ & 8 & $8(100)$ & $4(50)$ & $7(88)$ \\
\hline
\end{tabular}

with IgM conjugate (two control sera; table III) are most likely to be due to incomplete separation of immunoglobulins during chromatography. Indeed, some IgG was demonstrable by immuno-electrophoresis in fraction II.

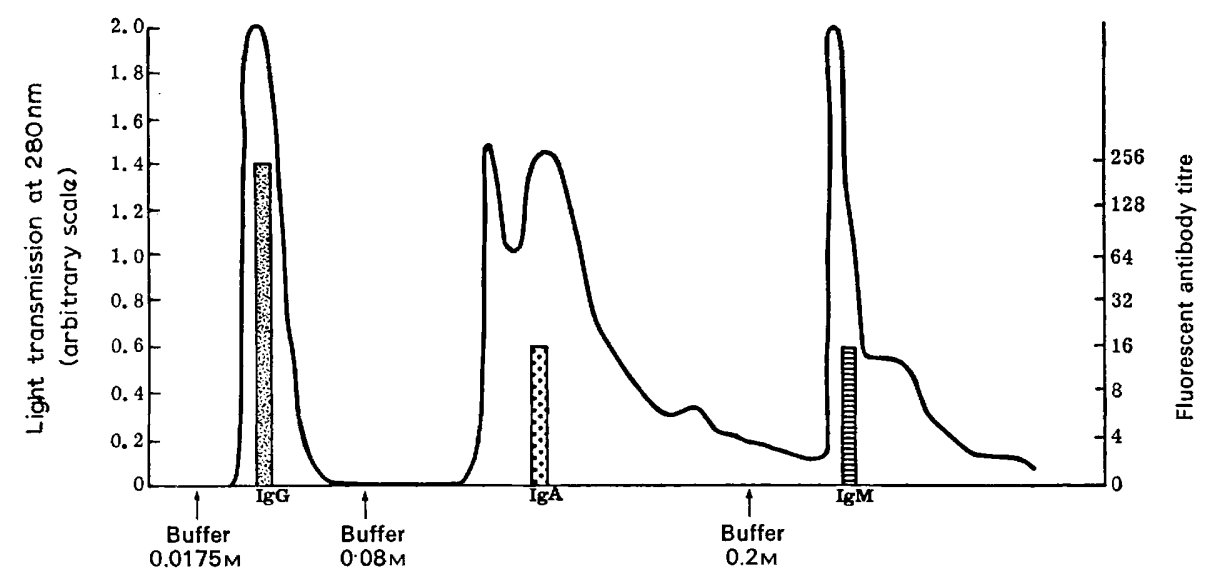

FigurE.-The distribution of IgG, IgA and IgM classes of candida antibodies, as determined by the fluorescent antibody test with DEAE cellulose chromatography fractions.

\section{Immunoglobulin concentration}

Significant differences were not established between controls and patients with candidosis (table IV). All four groups of candidosis had a slightly raised IgA concentration, and both acute varieties had elevated IgM levels. An individual and group comparison between the immunoglobulin concentration and candida antibody titre failed to yield a clear association. 


\section{TABLE III}

The distribution of immunoglobulin classes of antibodies to Candida albicans in separated fractions of serum

\begin{tabular}{|c|c|c|c|c|c|}
\hline \multirow{2}{*}{ Type of serum } & \multirow{2}{*}{$\begin{array}{l}\text { Serum or DEAE } \\
\text { chromatography } \\
\text { fractions }\end{array}$} & \multirow{2}{*}{$\begin{array}{l}\text { Major } \\
\text { Ig class }\end{array}$} & \multicolumn{3}{|c|}{$\begin{array}{l}\text { Antibody titre in fluoresence } \\
\text { tests with conjugates of }\end{array}$} \\
\hline & & & anti-IgG & anti-IgA & anti-IgM \\
\hline $\begin{array}{l}\text { Pooled serum from } \\
\text { four patients with } \\
\text { candidosis }\end{array}$ & $\begin{array}{l}\text { I } \\
\text { II } \\
\text { III } \\
\text { Whole serum }\end{array}$ & $\begin{array}{l}\operatorname{IgG} \\
\text { IgA } \\
\text { IgM }\end{array}$ & $\begin{array}{r}256 \\
4 \\
0 \\
512\end{array}$ & $\begin{array}{r}0 \\
16 \\
4 \\
64\end{array}$ & $\begin{array}{r}0 \\
0 \\
16 \\
32\end{array}$ \\
\hline $\begin{array}{l}\text { Chronic hyperplastic } \\
\text { candidosis }\end{array}$ & $\begin{array}{l}\text { I } \\
\text { II } \\
\text { III } \\
\text { Whole serum }\end{array}$ & $\begin{array}{l}\operatorname{IgG} \\
\operatorname{IgA} \\
\operatorname{IgM}\end{array}$ & $\begin{array}{r}16 \\
0 \\
0 \\
128\end{array}$ & $\begin{array}{r}0 \\
8 \\
0 \\
32\end{array}$ & $\begin{array}{l}0 \\
0 \\
0 \\
0\end{array}$ \\
\hline Control . & $\begin{array}{l}\text { I } \\
\text { II } \\
\text { III } \\
\text { Whole serum }\end{array}$ & $\begin{array}{l}\text { IgG } \\
\text { IgA } \\
\text { IgM }\end{array}$ & $\begin{array}{l}8 \\
0 \\
0 \\
8\end{array}$ & $\begin{array}{l}0 \\
1 \\
0 \\
0\end{array}$ & $\begin{array}{l}1 \\
0 \\
4 \\
4\end{array}$ \\
\hline Control . & $\begin{array}{l}\text { I } \\
\text { II } \\
\text { III } \\
\text { Whole serum }\end{array}$ & $\begin{array}{l}\operatorname{IgG} \\
\text { IgA } \\
\text { IgM }\end{array}$ & $\begin{array}{l}1 \\
0 \\
0 \\
4\end{array}$ & $\begin{array}{l}0 \\
0 \\
0 \\
0\end{array}$ & $\begin{array}{l}0 \\
0 \\
1 \\
0\end{array}$ \\
\hline Control & $\begin{array}{l}\text { I } \\
\text { III } \\
\text { Whole serum }\end{array}$ & $\begin{array}{l}\text { IgG } \\
\text { IgA } \\
\text { IgM }\end{array}$ & $\begin{array}{l}4 \\
0 \\
0 \\
4\end{array}$ & $\begin{array}{l}0 \\
2 \\
0 \\
2\end{array}$ & $\begin{array}{l}1 \\
0 \\
1 \\
2\end{array}$ \\
\hline
\end{tabular}

TABLE IV

Immunoglobulin concentrations in four types of candidosis and in controls

\begin{tabular}{|c|c|c|c|c|}
\hline \multirow{2}{*}{ Diagnosis } & \multirow{2}{*}{$\begin{array}{l}\text { Number } \\
\text { of subjects }\end{array}$} & \multicolumn{3}{|c|}{ Mean concentration $( \pm \mathrm{SE})$ in $\mathrm{mg}$ per $100 \mathrm{ml}$, of } \\
\hline & & IgG & $\operatorname{IgA}$ & $\operatorname{IgM}$ \\
\hline Controls & 30 & $1286( \pm 39 \cdot 6)$ & $175( \pm 10 \cdot 2)$ & $74( \pm 6 \cdot 2)$ \\
\hline Acute pseudomembranous candidosis & 9 & $1210( \pm 98 \cdot 5)$ & $268( \pm 36 \cdot 3)$ & $142( \pm 34)$ \\
\hline Acute atrophic candidosis & 8 & $1316( \pm 82 \cdot 0)$ & $271( \pm 35 \cdot 7)$ & $117( \pm 15 \cdot 1)$ \\
\hline Chronic hyperplastic candidosis & 12 & $1356( \pm 91 \cdot 2)$ & $234( \pm 36 \cdot 0)$ & $69( \pm 10 \cdot 8)$ \\
\hline Chronic atrophic candidosis & $4^{*}$ & 1306 & 262 & 96 \\
\hline
\end{tabular}

* Four other cases had Sjøgren's syndrome. 


\section{Discussion}

Antibodies to Candida albicans have been detected in the three main classes of immunoglobulins. In candidosis the rise in antibody titre is most frequently of the IgG type, to a less extent IgM and least commonly of the $\operatorname{IgA}$ class. IgG titres were raised in all patients with increased IgA or IgM levels, except in two patients who showed raised IgA titres (64 and 256), in the absence of significant IgG levels. The immunofluorescence test can be adequately performed with the IgG conjugate in 78 per cent. of patients, but in about 6 per cent. raised antibody titres will be missed because it belongs to the IgA class. There is no advantage in using the "triple" immunoglobulin conjugate, for the antibody titre reflects that of the IgG conjugate, and has not revealed raised levels in the two patients with elevated $\operatorname{IgA}$, in the absence of significant IgG titres. Controls which have not been differentiated from carriers, have IgA antibody titres of the same magnitude as that of $\operatorname{IgG}$, but the IgM level is lower (table I).

The result with the IgG conjugate is comparable with that with the antihuman globulin, reported previously (Lehner, 1965, 1966a). The titres recorded by Esterly (1968) using an anti-globulin conjugate were similar, but higher for controls as well as patients, and this might be explained by a difference in interpreting end-points, or in the fluorescein : protein ratio of the conjugates. However, in the preliminary studies, candida antibodies of the IgM class were apparently not detected by Esterly.

A comparison between the four types of candidosis revealed some differences in the class of antibody response. In acute and chronic atrophic candidosis almost all sera showed significant IgG antibody levels in comparison with only two-thirds in the acute pseudomembranous and chronic hyperplastic varieties. However, in acute atrophic candidosis the IgG titres were low and IgA and IgM failed to reach significant levels, or they were very low. In contrast, in chronic atrophic candidosis IgG titres were high and significant IgA and IgM levels were present in 50 per cent. and 88 per cent. of sera. IgM type antibodies were not predominantly elevated in the acute varieties of candidosis, as might have been expected on theoretical grounds.

Serum immunoglobulin levels of patients with candidosis showed raised IgA concentrations, but these did not reach the 5 per cent. level of significance (table IV). The four types of candidosis failed to show any distinguishing immunoglobulin pattern, except that the IgM levels were raised in both types of acute candidosis. No common trend was established between immunoglobulin concentration and candida antibody titre.

In chronic hyperplastic candidosis an immunoglobulin deficiency was not detected and the antibody response to candida was not greatly different from that seen in acute pseudomembranous candidosis. Five of these patients were children; two had localised mucocutaneous candidosis, two had the endocrine candidosis syndrome and one had chronic oro-ungual involvement without any manifest endocrine abnormality (Lehner, 1966b). All but one showed the raised IgG type of candida antibodies, and only one of them had a high IgM 
titre. A marked serum antibody response to candida was also established by Chilgren et al. (1967) and Louria et al. (1967), with the agglutination and precipitation tests and by Esterly with the fluorescent technique.

The sensitivity of the immunofluorescence test for the three classes of immunoglobulins is not known, although Cohen, Norins and Julian (1967) have shown with Neisseria gonorrhoeae that IgG may inhibit IgM reactivity. There is no evidence from the present study of candida antibodies, in which sera fractionated by DEAE cellulose chromatography were used, that there is competition between IgG, IgA and IgM for antigenic sites (table III). It is probable that this method does not favour any particular immunoglobulin class and may therefore reflect accurately the type of antibody response without the necessity of serum fractionation. This might be useful in serial determination of antibody titres of convalescent sera.

\section{SUMMARY}

The indirect fluorescent antibody technique was used to determine the titre and immunoglobulin class of antibodies to Candida albicans in sera from 65 subjects. In patients with candidosis, antibodies were detected in the three main classes of immunoglobulins; significant titres of IgG were found in 78 per cent. of them, of $\operatorname{IgM}$ in 51 per cent., and of $\operatorname{IgA}$ in 30 per cent. Some differences were also found in incidence, titre and immunoglobulin class between the four types of candidosis. Serum fractionation by DEAE cellulose chromatography confirmed that antibodies to Candida albicans are found in the three immunoglobulin classes. The concentrations of serum $\operatorname{IgG}, \operatorname{IgA}$ and $\operatorname{IgM}$ were also determined, but these failed to show significant differences between patients and controls. There was no correlation between the fluorescent antibody titre of a particular immunoglobulin class and the corresponding immunoglobulin concentration.

\section{REFERENCES}

Chilgren, R. A., Quie, P. G., Meuwissen, 1967. Lancet, $2,688$. AND HONG, R.

COHEN, I. R., Norins, L. C., AND 1967. J. Immun., 98, 143. Julian, A. J.

ESTERLY, NANCY B

LEHNER, $T$.

1968. Amer. J. Clin. Path., 50, 291.

1963. In Oral pathology in the child, New York, p. 75.

1965. Archs Oral Biol., 10, 975.

1966a. J. Path. Bact., 91, 97.

1966b. In Symposium on candida infections, ed. by $\mathbf{H}$. I. Winner and Rosalinde Hurley, Edinburgh and London, p. 119.

LeVY,"H. B., AND SOBER, M. A. ·.
LOURIA, D. B., SHanNon, D., JoHNSON, 1969. Archs Oral Biol., 14, 351.

1960. Proc. Roy. Soc. Med., 59, 50.

Louria, D. B., Shannon, D., Johnson,
G., Caroline, L., OKas, A., AND TASCHDJIAN, C.

Mancini, G., Carbonara, A. O., and Hereman, J. F.

1967. Trans. Assoc. Amer. Physns, 80, 236.

SCHEIDEGGer, J. J.

1963. In Protides of the biological fluids, ed. by H. Peeters, vol. XI, p. 3.

1955. Int. Archs Allergy Appl. Immun., 7, 103. 